\title{
sciendo
}

CIVIL AND ENVIRONMENTAL ENGINEERING REPORTS

E-ISSN 2450-8594

CEER 2019; 29 (2): 050-059

DOI: 10.2478/ceer-2019-0016

Original Research Article

\section{MEDICAL WASTE MANAGEMENT IN AL-BASHEER STATE HOSPITAL - CURRENT SITUATION AND FUTURE PROSPECTS}

\author{
Omar QTEISHAT ${ }^{1}$ \\ Civil Engineering Department, Faculty of Engineering Technology \\ Al-Balqa Applied University, Jordan
}

\begin{abstract}
In the Middle East and North Africa Jordan is considered as the top medical tourism due to the high level of medical specialized medical centers in the country. In Jordan Ministry of Health monitors, evaluate, enforces, and regulates requirements of medical waste management over medical waste instructions No. 1/2001. Al-Bashir Hospital is the largest hospital in Jordan. It is built on 156 acres and consists of 49 buildings and 80 departments. It has been reported that Al-Bashir Hospital has 1150 medical bed in 2019 and expected to increase to 1500 . About 3200 employee and 1100 clean workers give the medical treatment and service for 7000 patient per day and 1.5 million patient per year. The present situation of medical waste management in Al-Bashir Hospital has many problems. The most important is the pressure imposed by heavy population around the incineration unit in the Hospital. Furthermore, the change from incineration to autoclave is faced by high cost of the autoclaves. The quantity of medical waste created by Al-Bashir Hospital is up to 703.8 ton which constitutes about $33 \%$ of the total medical waste in Jordan. The high cost of fuel resulted in wrong acts in Al-Bashir Hospital like mixing medical waste with household waste and incineration at lower temperature (about $600{ }^{\circ} \mathrm{C}$ ). If the incineration unit in Al-Bashir Hospital is closed the expenses will range from US\$ 400,000 to 2.5 million.
\end{abstract}

Keywords: Bashear hospital, medical waste, management, Jordan, legislation

\footnotetext{
${ }^{1}$ Corresponding author: P.O Box 15008, Amman 11134- Jordan, e-mail: aliomar1111@yahoo.com
} 


\section{INTRODUCTION}

A waste is measured hazardous as it shows the features of presence infectious, reactive, corrosive, volatile, flammable, bio accumulative, annoying, or sensitizing [1]. Medical waste has different types which include pathology, biohazards, pharmaceutical, trace chemotherapy, immunizations, waste generated in autopsy and necropsy, waste produced in research relating to the production or testing of microbiological, waste created in research using human or animal pathogens, sharps and laboratory waste that causes a potential risk of infection to humans or any extra wastes that are produced from medical care bodies, such as medical laboratories, hospitals, clinics, and dental clinics [2]. Medical waste Management has been of great interest as a result of actually high dangers to human health and to the surrounding environment. In the past years, household wastes was often included medical wastes and assorted with then disposed in the same solid waste landfills.

Bangladesh is one of the developed countries with low health care. The hospitals produce about $5561 \mathrm{~kg} /$ day of wastes, nearly about $77.3 \%$ are non-medical hazardous and almost $22.7 \%$ are medical waste hazardous. The usual total waste produced rate for the measured hospital is $1.89 \mathrm{~kg} / \mathrm{bed} /$ day or $15 \mathrm{~kg} /$ patient/month. In general there is absence in suitable regular management of medical wastes except for a rare private hospitals that separate the medical wastes. Many hospitals employees were found to rescue used saline bags, sharps, bags of blood and test tubes for reuse or resale. Contrariwise medical waste management situation in developed countries, correct medical waste management is a novel sensation and governments are trying to improve and apply the new methods to agreement with the medical waste properly [3].

In Korea the generation of medical waste has been growing in magnitude and variation, because of the widespread approval of disposable medical items (e.g. plastic, gloves, medical packages syringes, tubing, containers, and bedding) [4]. Recently, increasing awareness in community over the unsuitable medical waste disposal have controlled to a drive to legalize the medical waste more methodically and rigorously by the Ministry of Environment in Korea. Controlling medical waste are still not practiced, thus treated of important amounts of medical wastes are to be in action. Until now burning of medical waste is the main method handling in Korea.

Studying the Medical waste management situation in the middle east for example in the United Arab Emirates (UAE), more than 850 medical center (hospitals and clinics) that produce risky medical wastes $[5,6]$. The main procedure of medical waste management in greatest states of the Middle East is burning; nevertheless, additional approaches that products less contamination are now actuality obtainable. 
The main objective of this study was to assessment the complications of medical waste management, governing, and medical waste management measures and control techniques in Al-Bashir hospital Amman/Jordan.

\section{METHODOLOGY}

The methodology followed in this research is a survey of published reports and news about Al-Bashir Hospital in the period of 2011-2019. The scarcity of information is due to the critical effect of information on the pressure imposed on the Jordanian Ministry of Health by public and Environmental societies. This work tries to shed some light about the quantity of medical waste produced by AlBashir Hospital, legislation applied, responsibilities, wrong acts and cost calculations.

\section{RESULTS AND DISCUSSION}

\subsection{Medical waste management in Jordan}

In Jordan due to high level of tourism high level of medical specialized medical centers in the country [4]. In Jordan there is 105 Hospitals (state and private) [8]. The expansion of healthcare services has been resulted an increase in the quantity of medical waste generated [4]. An estimated 11 ton/day (2012) of medical waste hazardous is produced all over the country [4]. Other references reported 7.5 ton medical waste per day which is equivalent to 2700 ton/year [8]. Most important types of medical waste are contaminated and infectious material (83\%) and sharp items $(12 \%)$, pharmaceuticals, chemicals $(1 \%)$, pathological waste, chemotherapeutic drugs residues (1\%), and emitting radiation substances [4]. However, private sector contributed in transportion, treatment, and collection [4]. The Country report on the solid waste management in Jordan (2014) detailed that: To a assured level, the medical waste must collected in color coded bags and containers and put in safekeeping storage facility until burned or autoclaved on specific location, or imparted to be incinerated in alternative site. A rare of incinerators have been established in military, university hospitals, public and private (20-30 units); not all of them meet the standards and purpose properly. Autoclaving is used in a very few facilities as well (3-5 units) [4].

The Environmental Health Manager in the Ministry of Health stated (16-3-2015) that $87 \%$ of the total medical waste in Jordan is subjected to treatment which are include incineration $(62 \%)$ and autoclaving $(25 \%)$ and the remaining $17 \%$ of waste is disposed using illegal methods [8]. 


\subsubsection{Legislation}

Ministry of Health monitors, enforces, and regulates medical waste management through medical waste management instructions No. 1/2001 [4]. This regulation defined the principles for transportation, collection, tentative storage in healthcare institutions, and treatment/disposal actions. Refer into four groups; radioactive, medical, hazardous and domestic wastes. Mixing wastes of these categories is not allowed. Furthermore, medical wastes are subdivided as pathologic, infectious and sharp materials which demand further separation monitored by incineration or correct sterilization. These regulations, which were published in state newsletters in 16-10-2001, are not continuously updated to adapt to changing conditions [12]. The regulation is too strict that it has limited values for the emission of $\mathrm{SO}_{2}$, dioxines and mercury from the incineration units, but the emission of these material has never been reported near the incineration units. The temperature of incinerators is specified at $1000-1200{ }^{\circ} \mathrm{C}$ and the retention of gases should be $2-5$ seconds [12], but the work of incineration units were never subjected to control or monitoring.

\subsubsection{Training}

For training a handbook on safety of medical waste management in Jordan which was funded by USAID, was created and a training course was implemented. Moreover a project to promotion eleven medical waste storage facilities in public hospitals of north Jordan [4].

\subsubsection{Wrong acts}

Some hospitals, which have no incineration units, disposed part of medical waste with the household waste to save the expenses of transportation and treatment of medical waste. Consequently, medical waste reaches Al-Ghabawi Landfill site and threatens the life of their workers [5]. Therefore, it should be noted that inefficient and improper segregation of medical and municipal waste, is still practiced, to varying extent, among healthcare facilities. Part of the medical waste generated ends up at municipal dumpsites along with municipal solid waste or it is even open burnt [4]. Moreover, some medical waste incineration units start burning medical waste at less than $600{ }^{\circ} \mathrm{C}$, which is wrong because burning should be initiated at $1000-2000{ }^{\circ} \mathrm{C}[5]$.

\subsubsection{Inspection}

Small number of inspectors from the Ministry of Health take a round over a large number of hospitals and healthcare centers. For examples, in 2012, 12 inspectors takes a round over 106 hospitals and medical center [5]. About 23 alerts were signed by the Ministry of Environment over the years 2010-2012 [5]. A huge 
number of small private clinical and dental centers which include medical laboratories are not subjected to regular inspection [5].

\subsubsection{Cost}

Healthcare centers pay the money for their medical waste management, which was paid throughout patients' bills. In addition to this of fuel and electricity costs was affect the cost of medical waste management [4]. The approximate cost for medical waste treatment and disposal in Jordan is about US\$ 600/ton. The cost for medical waste transport is US\$ 150 per trip, and the cost for incineration US\$ 0.7-1.4 per $\mathrm{kg}$ [4]. A private company for medical waste transportation and incineration is on work with a cost of US\$ 140 per trip and US\$ 0.8-1.4 per kg for incineration [5].

\subsubsection{Incineration activities}

In Jordan, there are 20 incineration units, 12 in state hospitals, 6 in Royal Medical Services, 2 in private hospitals [5]. A proposal for a project of central Jordanian incineration unit in "Al-Ghabawi Landdfill" was initially suggested in 2007, but deleted in 2012 [5]. Autoclave is a good replacement for the incineration because autoclave kills viruses and bacteria, but only three hospitals have autoclaves which are expensive (US\$ $350-450$ per unit) [5]. The replacement of incineration by autoclaving started in 2015 due to the problems in some of the incineration units in Jordan. The Ministry of Health imported 5 autoclave units in 2015 for state hospitals and gave license for 14 autoclave units for private hospitals [8].

\subsection{Medical waste management in Al-Bashir state Hospital}

Al-Bashir Hospital is the largest hospital in Jordan. It is built on 156 acres and consists of 49 buildings and 80 departments. It has been reported that Al-Bashir Hospital has 1150 medical bed in 2019 and expected to increase to 1500 . About 3200 employee and 1100 clean workers give the medical treatment and service for 7000 patient per day and 1.5 million patient per year [7]. This huge medical activity is expected to produce large amount of medical waste which threaten the life of workers, patients and the heavy population around the hospital. The 1150 medical beds in Al-Bashir Hospital constitute about 30\% of the total beds of Jordanian hospitals. Depending on the reported average of medical waste per bed per day reported by Ministry of Health $0.88 \mathrm{~kg} / \mathrm{bed} /$ day [10], the expected medical waste produced by Al-Bashir Hospital is $1012 \mathrm{~kg}$ per day 364 ton per year. The is number may be lower than the actual value since the turnover of patients on beds in Al-Bashir Hospital is very high and the $\mathrm{kg} / \mathrm{bed} /$ day values were reported to reach 1.36 [13], 1.13 [14] and $1.68 \mathrm{~kg} / \mathrm{bed} / \mathrm{day}$ [9] in North Jordanian Hospitals, Saudi Arabia and Istanbul, respectively. Furthermore, it has been announced that 
part of medical waste of Al-Bashir hospital is transported to Zarqa Incineration Unit, $1600 \mathrm{~kg}$ are treated in Al-Bashir incineration and autoclaves units [6].

\subsubsection{Legislation}

Report of strategy for risk management in Al-Bashir Hospital 2014-2017 include some points about medical wastes management. Procedure and policies followed in al-Bashir Hospital to avoid the risk of medical waste: medical waste should be disposed in containers equipped with colored bags and then stored and transported to the incineration unit. Yellow bags are for medical waste and black bags for nonmedical waste. Syringes and sharp tools are disposed in special boxes [1].

\subsubsection{Training}

The first training center for medical waste handling in Al-Bashir Hospital was started in 2005 by the aid of Canadian government. The training center was first initiated in Surgery Department as a trial center [3].

\subsubsection{Responsibilities}

Report of strategy for risk management in Al-Bashir Hospital 2014-2017 include some points about who is responsible for medical waste. Assistant manager is the main responsible, but the issue should be followed also by Departments managers, Quality Assurance and Training Department. There is no specialized department for medical waste management in Al-Bashir hospital [1]. The number of workers in the incineration unit in Al-Bahir Hospital is very low. One from nursing staff, one inspector and one laborer [6].

\subsubsection{Incineration activities}

The Assistance Manager in AL-Bashir Hospital announced in 2014 that the Ministry of Health permit specific amount of medical waste to be transported to Zarqa Incineration Unit and the reminder should be burned in the incineration unit of the Hospital [2].

The incineration unit in Al-Bashir Hospital was initiated in 1981, thus it is using very old technology. About $1200 \mathrm{~kg}$ of medical waste are burned per day (3-4 working hours) in this unit nowadays and $400 \mathrm{~kg}$ are treated in the more developed autoclaves [6]. On 21-2-2019, The Municipality of Amman (capital of Jordan) sent Ministry of Health a formal request to close the incineration unit in Al-Bashir Hospital [6], because the incineration unit is very close to the population mass [5]. 


\subsubsection{Cost}

The average medical waste generated is increasing dramatically each year. For example, medical waste amounts from Istanbul hospitals have increased from approximately 5307 ton in 2000 to 22,755 ton in 2017 [9]. Al-Bashir Hospital has 1150 medical bed in 2019 and this number is expected to increase to 1500, A significant increase in medical waste is expected to be associated with the increase of the number of beds [7].

In Al-Bashir Hospital $1200 \mathrm{~kg}$ medical waste is treated by incineration in the hospital and $400 \mathrm{~kg}$ are autoclaved [6]. If the incineration unit of the hospital is closed as a response to the pressure of people living near to the hospital, the cost of treatment of the medical waste should be calculated.

The critical number for determination of the amount of medical waste produced by Al-Bashir Hospital and the cost for treatment of this cost is the amount of $\mathrm{kg} / \mathrm{bed} /$ day. Qdais et al. (2007) reported that the daily unit medical waste in Jordan in 2007 is $0.29-1.36 \mathrm{~kg} /$ bed-day [13]. Al-Zahrani et al. (2000) estimated that the mean generation rate of medical waste from Saudi hospitals to be $1.13 \mathrm{~kg} /$ bed-day [14]. In Istanbul hospitals, the daily unit medical waste amounts per hospitals bed have increased from $0.43 \mathrm{~kg} / \mathrm{bed}$-day in 2000 to $1.68 \mathrm{~kg} /$ bed-day in 2017 in Istanbul hospitals [9]. Ministry of Health in Jordan reported an average of $0.88 \mathrm{~kg} / \mathrm{bed} /$ day [10]. Taking the average to be $1.5 \mathrm{~kg} / \mathrm{bed}$-day, it can be calculated that $1725 \mathrm{~kg}$ of medical waste is generated per day in Al-Bashir Hospital, and consequently, 621 ton are generated yearly.

If the incineration unit is to be closed and taking into account that the cost of medical waste treatment in Jordan is about US\$ 600/ton [4], then the yearly cost for medical waste generated from Al-Bashir Hospital will be US\$372,600. If the average incineration cost in Jordan is US\$ 1.1 per $\mathrm{kg}$ [4], and the medical waste generated could be incinerated in the proposed central incineration unit, then the yearly cost for medical waste generated from Al-Bashir Hospital will be US\$ 683,100 plus transportation cost.

The distance between Al-Bashir Hospital and Al-Ghabawi Landfill which is proposed to host the incineration unit is $31 \mathrm{~km}$ and the cost of transportation is US\$ $0.43 / \mathrm{km} /$ ton [10]. Thus, the yearly cost for transportation is US\$ 8, 278. Calculation regarding the amount produced by the total state hospitals in Jordan and Al-Bashir Hospital specifically and costs are given in Tables 1 and 2, respectively. 
Table 1. The amount of medical waste produced by the total state hospitals in Jordan and Al-Bashir Hospital

\begin{tabular}{|c|c|c|c|c|c|}
\hline Hospital & $\begin{array}{c}\text { Number } \\
\text { of beds }\end{array}$ & \multicolumn{2}{|c|}{$\begin{array}{c}\text { Medical waste produced } \\
\text { in kg per day }\end{array}$} & \multicolumn{2}{|c|}{$\begin{array}{r}\text { Medical waste produced } \\
\text { in ton per year }\end{array}$} \\
\hline $\begin{array}{c}\text { Base of } \\
\text { calculations }\end{array}$ & - & $\begin{array}{c}\text { Lower value } \\
0.3 \mathrm{~kg} / \mathrm{bed} / \mathrm{day}\end{array}$ & $\begin{array}{c}\text { Upper value } \\
1.7 \mathrm{~kg} / \mathrm{bed} / \mathrm{day}\end{array}$ & $\begin{array}{c}\text { Lower value } \\
0.3 \mathrm{~kg} / \mathrm{bed} / \mathrm{day}\end{array}$ & $\begin{array}{c}\text { Upper value } \\
1.7 \mathrm{~kg} / \mathrm{bed} / \mathrm{day}\end{array}$ \\
\hline Al-Bashir & 1150 & 345 & 1955 & 124.2 & 703.8 \\
\hline $\begin{array}{c}\text { All } \\
\text { Jordanian } \\
\text { State } \\
\text { Hospitals }\end{array}$ & 3500 & 1050 & 5950 & 378.0 & 2142.2 \\
\hline
\end{tabular}

Table 2. The cost of medical waste produced by the total state hospitals in Jordan and Al-Bashir Hospital if the treatment of waste is outside hospitals

\begin{tabular}{|c|c|c|c|c|c|}
\hline \multirow[t]{2}{*}{ Hospital } & \multirow[t]{2}{*}{$\begin{array}{l}\text { Number } \\
\text { of beds }\end{array}$} & \multicolumn{2}{|c|}{$\begin{array}{l}\text { Cost of incineration outside } \\
\text { hospital* (US\$ per year) }\end{array}$} & \multicolumn{2}{|c|}{$\begin{array}{l}\text { Cost of transportation from } \\
\text { hospital to Al-Ghabawi proposed } \\
\text { incineration unit } * * \text { (US\$ per } \\
\text { year) }\end{array}$} \\
\hline & & $\begin{array}{l}\text { Lower value } \\
0.3 \mathrm{~kg} / \mathrm{bed} / \text { day }\end{array}$ & $\begin{array}{l}\text { Upper value } \\
1.7 \mathrm{~kg} / \mathrm{bed} / \text { day }\end{array}$ & $\begin{array}{l}\text { Lower value } \\
0.3 \mathrm{~kg} / \mathrm{bed} / \text { day }\end{array}$ & $\begin{array}{l}\text { Upper value } \\
1.7 \mathrm{~kg} / \mathrm{bed} / \text { day }\end{array}$ \\
\hline $\begin{array}{c}\text { Al- } \\
\text { Bashir }\end{array}$ & 1150 & 156,420 & 774,180 & $1,655.5$ & $9,371.0$ \\
\hline $\begin{array}{l}\text { All } \\
\text { Jordanian } \\
\text { State } \\
\text { Hospitals }\end{array}$ & 3500 & 415,800 & $2,356,420$ & $9,752.4$ & $55,268.8$ \\
\hline
\end{tabular}

* Calculations based on incineration cost in Jordan of US\$1.1/kg.

** Calculations based on transportation cost in Jordan of US\$ $0.43 / \mathrm{km} / \mathrm{ton}$.

\section{CONCLUSIONS}

The present situation of medical waste management in Al-Bashir Hospital has many problems. The most important is the pressure imposed by heavy population around the incineration unit in the Hospital. Furthermore, the change from incineration to autoclave is faced by high cost of the autoclaves. The amount of medical waste produced by Al-Bashir Hospital is up to 703.8 ton which constitutes about $33 \%$ of the total medical waste in Jordan. The high cost of fuel resulted in wrong acts in Al-Bashir Hospital like mixing medical waste with household waste and incineration at lower temperature (about $600{ }^{\circ} \mathrm{C}$ ). If the incineration unit in Al-Bashir Hospital is closed the expenses will range from US\$ 400,000 to 2.5 million. 


\section{ACKNOWLEDGEMENT}

This study was supported by Al-Balqa Applied University during my Sabbatical leaf. Grateful thanks and sincere gratitude for Al-Balqa' Applied University.

\section{REFERENCES}

[1] LaGrega, MD, Buckingham, PL and Evans, JC 2001. Hazardous Waste Management, 2nd Edition, Mc-Graw Hill.

[2] US Congress, Office of Technology Assessment, Issues in Medical Waste Management -Background Paper. 1988, US Government Printing Office, Washington DC.

[3] Hassan, MM, Ahmed, SA, Rahman, KA and Biswas, TK 2008. Pattern of Medical Waste Management: Exist-ing Scenario in Dhaka City, Bangladesh, BMC Public Health 8, 36, doi:10.1186/1471-2458-8-36.

[4] Jang, YC, Lee, C, Yoon, OS and Kim, H 2006. Medical Waste Management in Korea. Journal of Environmental Management 80, 107-115. doi:/10.1016/j.jenvman.2005.08.018.

[5] UAE Yellow Pages, "Clinics and Hospitals, 2010.

http://www.yellowpages.ae/category/clinics-/ http://www.scribd.com /doc/4100881/

[6] Middle East Health Care Intelligence, 2010.

http://biomedme.com/uae/dubaisclemenceau-medical-center- amongst-topten-best-hospitals-for-medical-tourism_6555. html

[7] Country report on the solid waste management in JORDAN, 2014, http://moenv.gov.jo/AR/LegislationAndPolicies/Policies/Documents/Form s/AllItems.aspx

[8] Khaberni News, Autoclaves costing 1 million JOD for medical waste management, 16-3-2015 www.khaberni.com/news/144402

[9] Regulation for medical waste management, Ministry of Health, 16-10-2001, http://www.moh.gov.jo/Echobusv3.0/SystemAssets/18400f6b-e1f7-4132b6d0-9101e357f4ba.pdf

[10] Faten Obaidat, Medical waste threatens health and environment, Alrai News, 20-11-2012 http://alrai.com/article/551824.html

[11] Al-Sabeel News, Rehabilitation of Al-Bashir Hospital, 25-2-2015 http://assabeel.net/

[12] Medical and industrial waste treatment plant for the Greater Amman Area and middle governorates under a boot scheme, 18-1-2018 http://moenv.gov.jo/AR/Environmental_sectors/Waste/Documents/Forms/ AllItems.aspx 
[13] Qdais, HA, Rabi, A and Abdulla, F 2007. Characteristics of the medical waste generated at the Jordanian hospitals. Clean Techn. Environ. Policy $\mathbf{9}$, 147-152.

[14] Al-Zahrani, MA, Fakhri, ZI, Al-Shanshouri, MA and Al-Ayed, MH 2000. Healthcare risk waste in Saudi Arabia: Rate of generation. Saudi Med. J. 21, 245-250.

[15] Korkut, EN 2018. Estimations and analysis of medical waste amounts in the city of Istanbul and proposing a new approach for the estimation of future medical waste amounts. Waste Management 81, 168-176.

[16] Strategy of risk and general health management in Al-Bashir Hospital, 20142017. http://www.albashir-hospital.gov.jo/

[17] Addustour News, 13-1-2005, Opening of training center in Al-Bashir Hospital for medical waste management, https://www.addustour.com.

[18] Albosala News, Ministry of Environment request Ministry of Heath to close the incineration unit in Al-Bashir Hospital, 21-6-2011 http://albosa.la/TXpFd01UUT0rdQ.

[19] Gerasa News, 31-03-2014, Continuation of incineration of medical waste in Al-Bashir Hospital is catastrophic, http://www.gerasanews.com/article/141460.

Editor received the manuscript 15.06.2019 